\title{
The Utilization of Pseudomonas taetrolens to Produce Lactobionic Acid
}

\author{
Kamila Goderska • Artur Szwengiel • Zbigniew Czarnecki
}

Received: 29 November 2013 / Accepted: 19 June 2014 /

Published online: 1 July 2014

(C) The Author(s) 2014. This article is published with open access at Springerlink.com

\begin{abstract}
Lactobionic acid is a relatively new product derived from lactose oxidation, with high potential applications as a bioactive compound. Conducted experiments confirmed that both the time and temperature influenced the production of lactobionic acid during bioconversion of lactose using the Pseudomonas taetrolens bacteria. The study also investigated the effect of inoculum concentration on the production of lactobionic acid as a result of oxidation of whey-derived lactose. The highest concentration of lactobionic acid during oxidation of whey-derived lactose at a temperature of $30{ }^{\circ} \mathrm{C}$ by microorganisms. P. taetrolens was obtained during 50 -h oxidation of the medium, which contained $25 \%$ addition of the inoculum, in which the count of live cells was $2.85 \times 10^{9} \mathrm{CFU} / \mathrm{ml}$.
\end{abstract}

Keywords Lactobionic acid $\cdot$ Lactose $\cdot$ Whey $\cdot$ Pseudomonas taetrolens

\section{Introduction}

Lactobionic acid (LBA) is a relatively new product derived from lactose oxidation, with high potential applications as a bioactive compound.

Lactobionic acid is an aldonic acid obtained from the oxidation of lactose, with the high potential application as an ingredient in foods and pharmaceutical products because of its antioxidant, chelating and humectant properties [1]. The chemical structure of lactobionic acid comprise a galactose moiety linked to a gluconic acid molecule via an ether-like linkage.

Lactobionic acid is also used in calcium supplementation and represents a new ingredient in skin care products featuring potent antioxidant and humectant properties. In the food industry, lactobionic acid can be used as an acidulant with a sweet taste; as filler in cheese production; as firming agent, and to fortify functional drinks with essential minerals such as $\mathrm{Fe}$ and $\mathrm{Cu}$ [4].

Lactobionic acid is of value for medical and cosmetic purposes. Because of its efficient metal-chelating properties, lactobionic acid reduces oxidative damage to tissues during storage. Hence, it is used as a major component of organ preservation solutions during transplantation [4].

K. Goderska $(\bowtie) \cdot$ A. Szwengiel $\cdot$ Z. Czarnecki Faculty of Food Technology and Nutrition, Institute of Food Technology of Plant Origin, Poznan University of Life Sciences, Poznan, Poland e-mail: kamilag@up.poznan.pl 
Zymomonas mobilis, a strictly fermentative gramme-negative ethanologenic bacterium, obtains its metabolic energy anaerobically via the Entner-Doudoroff pathway [2]. The ability of $Z$. mobilis to grow on high glucose concentration was originally explained by a rapid equilibration of the external and internal glucose concentrations achieved by the glucose facilitator system. The ability of $Z$. mobilis to counteract detrimental osmotic effects when grow on sucrose or mixtures of glucose and fructose has been attributed to the formation of sorbitol as a result of the activity of glucose-fructose oxidoreductase (GFOR).

Lactose is the only disaccharide present in milk and also in whey; it is a cheap industrial product obtained in abundant tonnage [3]. Recent papers by Druliolle et al., have shown that the electrocatalytic oxidation of lactose on noble metal electrodes in alkaline media permits us to form lactobionic acid with a high selectivity. Electrolysis carried out on $\mathrm{Au}$ electrodes showed that the conversation yield decreases when the initial concentration of lactose increase [3].

Lactose is mainly used as an ingredient in foods, beverages and confectionery products, and it has been extensively employed as diluent in tablets and carrier of medicines in the pharmaceutical industry. Nevertheless, the use of lactose is limited in many applications, because of its low sweetness and solubility, as well as due to the intolerance of some population segments, and only a small amount of lactose is employed as a raw material for producing fine chemicals [4].

However, the worldwide surplus and low cost of lactose have motivated research on innovative processes for producing valuable lactose derivatives, and expanding their applications in the food, pharmaceutical and chemical industries. Significant developments include the production of highly valued pharmaceutical products and functional food ingredients, such as lactitol, lactobionic acid (LBA), lactosucrose, lactulose and galacto-oligosaccharides, some of which have become commercially successful [5].

A new carbohydrate oxidase, lactose oxidase, with high specificity of oxidizing the disaccharide lactose to lactobionic acid has been found by Ahmad et al. 2004.

A programme of toxicological studies was conducted to establish the safety of lactose oxidase to be used as a processing aid in the food industry. The enzyme used in this study was produced by a submerged fermentation of Fusarium venenatum and contained a gene code from Microdochium nivale [6].

In food technology, lactobionic acid may find applications due to its ability to form mineral salt complexes and its presumed prebiotic effect. One of the new applications in focus is converting lactose in milk to lactobionic acid and exploiting the desirable characteristics of lactobionic acid to replace proteins and/or fats in process, cheeses and cream cheese. Lactobionic acid may even be seen as a flavour enhancer, a texture builder, and antioxidant synergist [6].

\section{Materials and Methods}

Microorganisms and Cultivation

\section{Microorganism}

Pseudomonas taetrolens DSM 21104 obtained from the Leibiniz-Institut DSMZ-German Collection of Microorganisms and Cell Cultures, was maintained frozen (in $40 \%[v / v]$ glycerol at $20^{\circ} \mathrm{C}$ ). This strain was subsequently subcultured on Tryptone Soya (Casein soya bean digest) (Oxoid, England) agar plates, incubated for $48 \mathrm{~h}$ at $30^{\circ} \mathrm{C}$ and then preserved at $4{ }^{\circ} \mathrm{C}$. 


\section{Inoculum Preparation}

A loopful of $P$. taetrolens from a fresh Tryptone Soya agar plate was used to inoculate a 500-mL Erlenmeyer flask containing 100-mL of Tryptone Soya broth medium. This flask was incubated on an orbital shaker at $250 \mathrm{rpm}$ and $30{ }^{\circ} \mathrm{C}$ for $24 \mathrm{~h}$. Active-growing cells from this culture were then employed as inoculum for the production of lactobionic acid in shake flasks and bioreactor seed cultures containing sweet whey, as subsequently reported.

\section{Rennet Whey Preparation}

Rennet whey ( $\mathrm{pH}=6.3$, amount of lactose $30 \mathrm{mg} / \mathrm{mL}$ ) (OSM Company TOP TOMYSL, Nowy Tomysl, Poland) was onefold diluted with distilled water (1:1) and adjusted to $\mathrm{pH} 6.5$ (by adding $\mathrm{NaOH} 6 \mathrm{~N}$ ) prior to sterilization using a tangential microfiltration device equipped with a PVDF membrane cassette of $0.22-\mu \mathrm{m}$ pore size (Millipore, MA, USA).

\section{Preparative Scale Batch Reactions}

Batch cultivations were performed in a 2 -L bioreactor $\left(\right.$ Biostat ${ }^{\circledR} B$, B. Braun Biotech International, Germany) with $1 \mathrm{~L}$ of whey as working volume, with aeration at $1 \mathrm{vol}^{-1} \mathrm{~min}^{-1}$ and agitation at $120 \mathrm{rpm}$ at $30^{\circ} \mathrm{C}$. Bioreactor experiments with an inoculation level of $10 \%(\mathrm{v} / \mathrm{v})$ were conducted at $30^{\circ} \mathrm{C}$. The bioreactor was equipped with a $\mathrm{pH}$ metre and a polarographic dissolved oxygen electrode in order to measure $\mathrm{pH}$ values online and continuously monitor dissolved oxygen tension (DOT), respectively. An efficient two-stage $\mathrm{pH}$-shifted bioconversion strategy was adopted as previously described [7]: $\mathrm{pH}$ was controlled above 6.5 (pH was left uncontrolled above this value during the growth phase and subsequently maintained at 6.5 ) by means of computer-controlled peristaltic pumps via automatic addition of 2-M NaOH. These prior conditions were applied to all cultivations unless otherwise specified. Cultivations were carried out in duplicate as independent experiments.

\section{Disruption of Cells}

Washed bacteria in acetic buffer $(0.05 \mathrm{M}, \mathrm{pH}=5.0)$ were disrupted by sonication (Polsonic, Palczynski Sp. J) at $80 \mathrm{~W}$ for a total time of $30 \mathrm{~min}$. The temperature was kept below $4^{\circ} \mathrm{C}$ by placing the sonication vessel in an ice bucket filled with ice. Cell was removed by centrifugation at $15,000 \mathrm{~g}$ for $30 \mathrm{~min}$ at $4{ }^{\circ} \mathrm{C}$. To obtain the high-speed supernatant fraction, cell-free extracts were centrifuged at $15,000 \mathrm{~g}$ for $30 \mathrm{~min}$. This fraction was used either immediately or stored at $-20^{\circ} \mathrm{C}$.

\section{Estimation of Protein}

The protein content of cell-free extracts and high-speed supernatants were determined by using the method of Bradford. Bovine serum albumin was employed as standard [8].

Analysis of Lactose and Lactobionic Acid

Lactose and lactobionic acid were measured by Alliance HPLC (Waters) on Rezex ROAOrganic Acid column $(300 \times 7.8 \mathrm{~mm}$; Phenomenex International, Torrance, CA, USA) at $210 \mathrm{~nm}$ - RI detector and PAD detector with an eluent of 0.025-M sulfuric acid, at a flow rate of $0.5 \mathrm{ml} \mathrm{min}^{-1}$. All samples were centrifuged to remove the cell mass and other waterinsoluble substances, and then filtered through a $0.22-\mu \mathrm{m}$ filter before the analysis. 


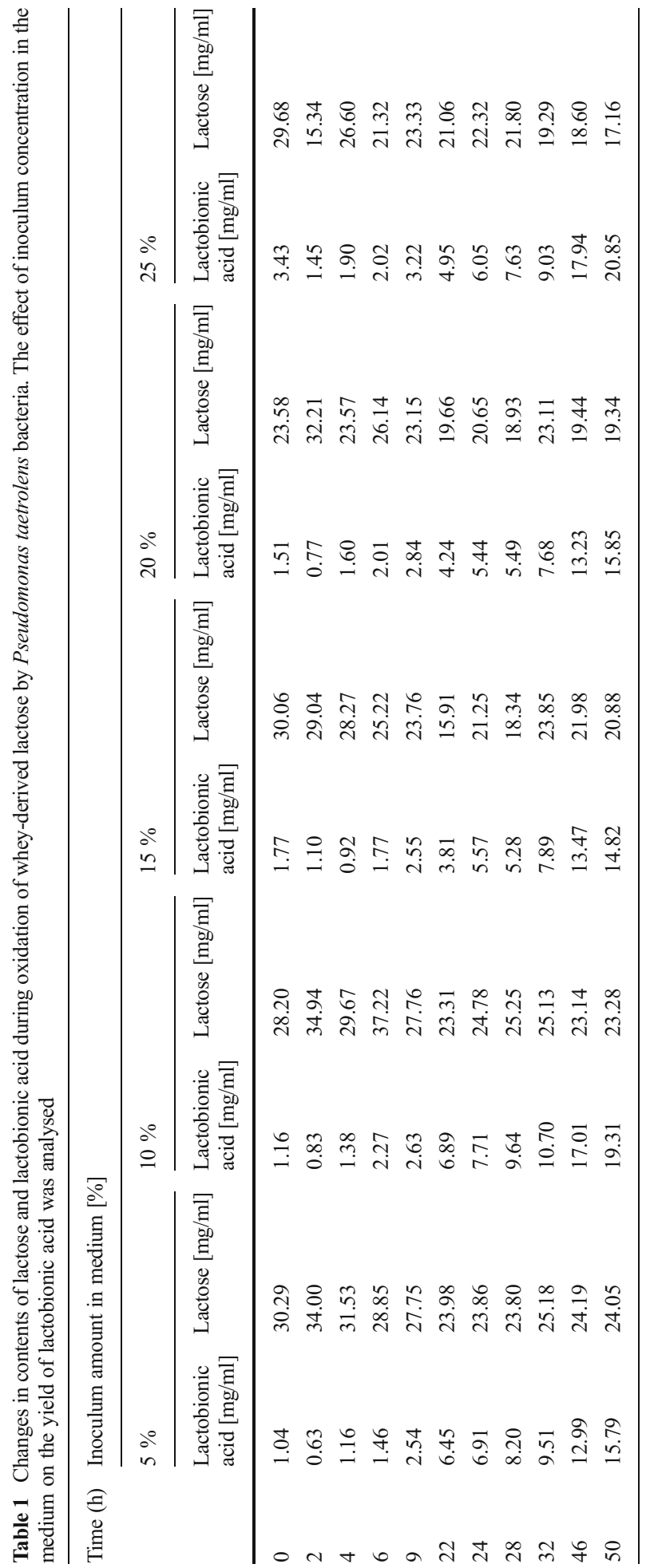


Characterization of the Production Microorganisms

The number of viable bacteria in each culture was determined by plate count on Tryptone Soya (Casein soya bean digest) (Oxoid, England) at $30^{\circ} \mathrm{C}$ for $24 \mathrm{~h}$. The number of live (CFU/ml) bacteria was determined using the Koch's plate method [9].

\section{Results}

Table 1 presents changes in the contents of lactose and lactobionic acid during oxidation of whey-derived lactose by enzymes produced by microorganisms $P$. taetrolens. The effect of inoculum concentration $(5,10,15,20$ and $25 \%)$ in the medium was analysed. Samples were collected immediately after inoculum was added to whey $(0 \mathrm{~h})$, as well as at 2, 4, 6, 9, 22, 24, 28, 32, 46 and $50 \mathrm{~h}$, as presented in Table 1.

The highest concentrations of lactobionic acid during oxidation of whey-derived lactose by microorganisms $P$. taetrolens were recorded at $50 \mathrm{~h}$ of oxidation in a medium, which contained $25 \%$ added inoculum. The reaction was run at a temperature of $30{ }^{\circ} \mathrm{C}$.

The experiment may be repeated, extending culture time in order to verify changes in contents of lactobionic acid and lactose, since in the presented results, the maximum content of lactobionic acid was recorded in the last hour of culture.

Moreover, the number of live microbial cells was determined using Koch's plate method [9] at $24 \mathrm{~h}$ of culture. Inoculation results are presented below.

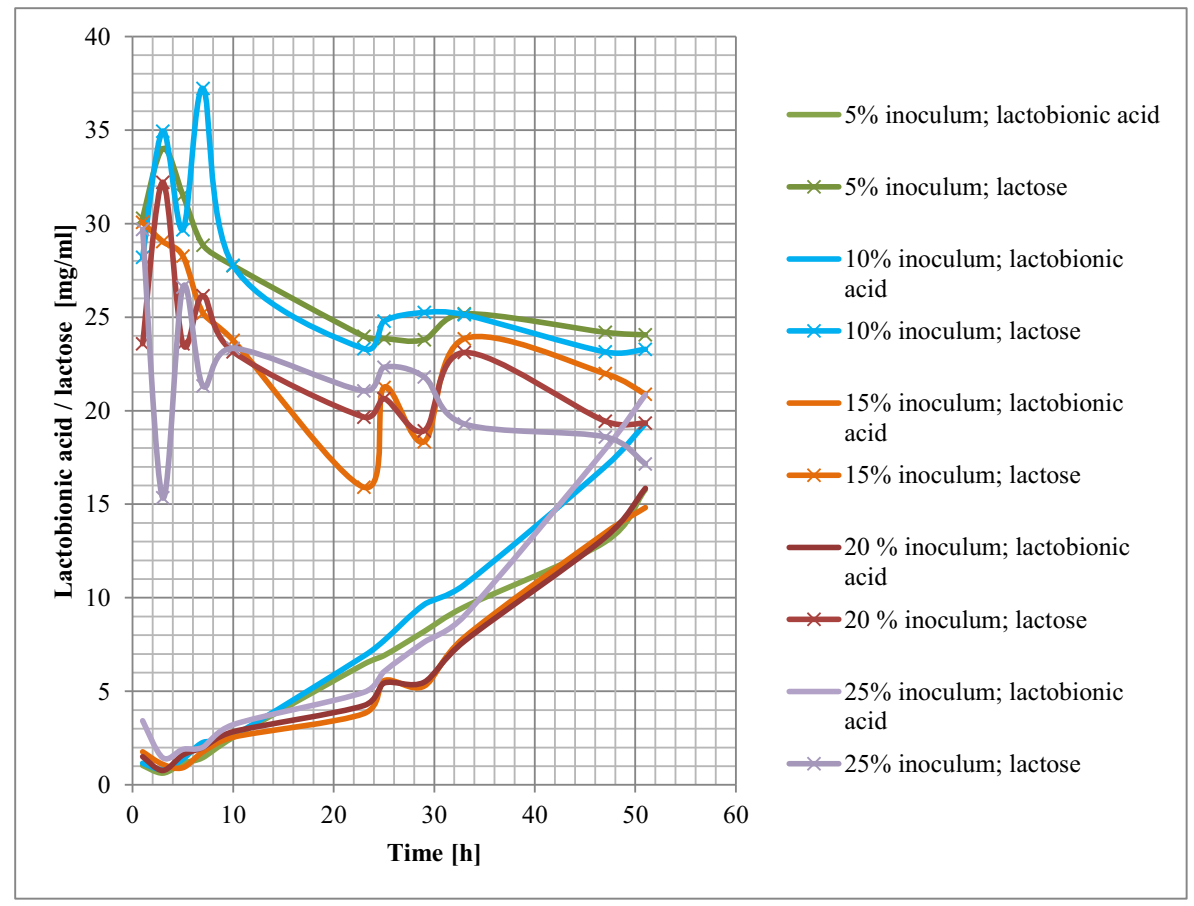

Fig. 1 Changes in contents of lactose and lactobionic acid in culture with a 5, 10, 15, 20 and $25 \%$ share of inoculum 
Table 2 The number of live microbial cells determined at $24 \mathrm{~h}$ of culture with different concentrations of added inoculum $[\mathrm{CFU} / \mathrm{ml}]$

\begin{tabular}{ll}
\hline Inoculum amount $(\%)$ & Colony forming units $[\mathrm{CFU} / \mathrm{ml}]$ \\
\hline 5 & $2.9 \times 10^{7}$ \\
10 & $3.2 \times 10^{8}$ \\
15 & $9.6 \times 10^{8}$ \\
20 & $1.39 \times 10^{9}$ \\
25 & $2.85 \times 10^{9}$ \\
\hline
\end{tabular}

Changes in contents of lactose and lactobionic acid during culture with different percentage concentrations of inoculum added to the medium are presented in Fig. 1. and Table 2.

The next experiment consisted in the stationary culture of microorganisms $P$. taetrolens in a bioreactor. Conditions found in the fermentation chamber were as follows: temperature $30{ }^{\circ} \mathrm{C}$, $\mathrm{pH}$ 6.7, aeration rate $1 \mathrm{l} / \mathrm{min}$ and mixing at $120 \mathrm{rpm}$. The experiment was repeated three times. Results listed in Table 3 were averaged. Lactobionic acid was produced as a result of enzymatic oxidation of whey-derived lactose [7]. The highest content of lactobionic acid was obtained at $144 \mathrm{~h}$ of culture.

The number of live microbial cells was determined using Koch's platelet method. Results of inoculations are presented in Tables 4, 5, 6 and 7

The culture in the bioreactor may be run for a longer time to continue the analysis of changes in the contents of lactobionic acid and lactose, which results from the fact that the highest acid content was recorded at $144 \mathrm{~h}$ of culture. As it is a stationary culture, it may be expected that after some time, nutrients (lactose) may be depleted or microorganisms will be toxified by products of their own metabolism and will no longer produce lactobionic acid.

The next experiment consisted in the culture of microorganism, P. taetrolens, by continuous culture with constant inflow of fresh sterile whey to the bioreactor. Conditions found in the fermentation chamber were as follows: temperature $30^{\circ} \mathrm{C}, \mathrm{pH} 6.7$, aeration rate $1 \mathrm{l} / \mathrm{min}$ and mixing $120 \mathrm{rpm}$. The experiment was repeated three times. At every $24 \mathrm{~h}$, the volume of 500$\mathrm{ml}$ culture was collected and it was supplemented with 500-ml sterilised whey. Samples were collected at every $12 \mathrm{~h}$. Results are presented in the table below.

The above discussed investigations demonstrated that $P$. taetrolens DSM 21104 is capable of utilising lactose in metabolic processes as a carbon source. Growth of $P$. taetrolens demonstrated that under carbon-limited conditions, the cells were able to utilise lactose.

Table 3 Changes in contents of lactose and lactobionic acid during oxidation of whey-derived lactose by microorganisms Pseudomonas taetrolens (the number of culture I, II and III)

\begin{tabular}{|c|c|c|c|c|c|c|c|c|}
\hline \multirow[t]{2}{*}{ Time $(\mathrm{h})$} & \multicolumn{4}{|c|}{ Lactobionic acid [mg/ml] } & \multicolumn{4}{|c|}{ Lactose $[\mathrm{mg} / \mathrm{ml}]$} \\
\hline & I & II & III & $\mathrm{X}$ & I & II & III & $\mathrm{X}$ \\
\hline 0 & 0.39 & 0.46 & 0.17 & 0.34 & 26.16 & 27.13 & 26.72 & 26.67 \\
\hline 24 & 1.59 & 1.17 & 1.74 & 1.50 & 17.54 & 19.23 & 23.11 & 19.96 \\
\hline 48 & 7.09 & 7.24 & 8.02 & 7.45 & 20.93 & 19.12 & 19.54 & 19.86 \\
\hline 72 & 10.36 & 9.76 & 11.15 & 10.42 & 18.36 & 18.01 & 18.67 & 18.35 \\
\hline 96 & 15.85 & 16.15 & 16.12 & 16.04 & 17.33 & 16.99 & 16.05 & 16.79 \\
\hline 120 & 22.31 & 22.43 & 21.89 & 22.21 & 15.25 & 15.89 & 15.34 & 15.49 \\
\hline 144 & 26.74 & 27.12 & 31.14 & 28.33 & 13.90 & 12.99 & 13.06 & 13.32 \\
\hline
\end{tabular}


Table 4 Changes in Pseudomonas taetrolens counts during stationary culture run in a bioreactor

\begin{tabular}{ll}
\hline Time $(\mathrm{h})$ & Counts of Pseudomonas taetrolens $[\mathrm{CFU} / \mathrm{ml}]$ \\
\hline 0 & $5 \times 10^{7}$ \\
24 & $3.3 \times 10^{8}$ \\
48 & $3.4 \times 10^{8}$ \\
72 & $3.7 \times 10^{8}$ \\
96 & $3.8 \times 10^{8}$ \\
120 & $4.9 \times 10^{8}$ \\
\hline
\end{tabular}

\section{Electrophoretic Analysis of Proteins in Cultures of Pseudomonas Taetrolens}

Proteins searched for and analysed in cultures of $P$. taetrolens were exocrine enzymes

- lactose oxidase with molecular mass of $55 \mathrm{kDa}$ [6]

- and lactonase with molecular mass of $28 \mathrm{kDa}$ [10]

\section{Determination of the Number of Live Bacterial Cells of Pseudomonas Taetrolens in the Process of Oxidation of Lactose to Lactobionic Acid Using Koch's Platelet Method}

The number of live microbial cells of $P$. taetrolens was determined in the process of oxidation of lactose to lactobionic acid [9]. Inoculations were conducted from the inoculum culture at $24 \mathrm{~h}$ of incubation at $30{ }^{\circ} \mathrm{C}$, from the stationary culture run in a bioreactor after $24 \mathrm{~h}$ of culture, and from the continuous culture run in a bioreactor at $24 \mathrm{~h}$ of culture.

Table 5 Changes in contents of lactose and lactobionic acid during oxidation of whey-derived lactose during continuous culture of microorganisms Pseudomonas taetrolens (the number of culture I, II, III).

\begin{tabular}{|c|c|c|c|c|c|c|c|c|}
\hline \multirow[t]{2}{*}{ Time (h) } & \multicolumn{4}{|c|}{ Lactobionic acid [mg/ml] } & \multicolumn{4}{|c|}{ Lactose $[\mathrm{mg} / \mathrm{ml}]$} \\
\hline & I & II & III & $X$ & I & II & III & $\mathrm{X}$ \\
\hline 0 & 0.55 & 0.58 & 0.53 & 0.55 & 35.23 & 33.57 & 37.30 & 35.37 \\
\hline 12 & 1.89 & 2.01 & 1.82 & 1.91 & 33.76 & 32.17 & 35.74 & 33.89 \\
\hline 24 & 5.73 & 6.09 & 5.54 & 5.79 & 30.32 & 28.89 & 32.10 & 30.44 \\
\hline 36 & 8.37 & 8.90 & 8.09 & 8.45 & 27.70 & 26.40 & 29.33 & 27.81 \\
\hline 48 & 8.58 & 9.11 & 8.28 & 8.66 & 27.27 & 25.99 & 28.88 & 27.38 \\
\hline 60 & 8.95 & 9.51 & 8.65 & 9.04 & 22.33 & 21.28 & 23.65 & 22.42 \\
\hline 72 & 9.08 & 9.65 & 8.77 & 9.17 & 24.32 & 23.18 & 25.75 & 24.42 \\
\hline 84 & 14.67 & 15.59 & 14.17 & 14.81 & 20.24 & 19.29 & 21.43 & 20.32 \\
\hline 96 & 15.28 & 16.24 & 14.76 & 15.43 & 19.85 & 18.91 & 21.01 & 19.92 \\
\hline 108 & 15.80 & 16.79 & 15.27 & 15.95 & 21.63 & 20.61 & 22.90 & 21.71 \\
\hline 120 & 16.35 & 17.37 & 15.79 & 16.51 & 19.82 & 18.88 & 20.98 & 19.98 \\
\hline 132 & 21.45 & 22.79 & 20.72 & 21.65 & 19.80 & 18.87 & 20.97 & 19.88 \\
\hline 144 & 27.50 & 29.22 & 26.56 & 27.76 & 20.13 & 19.18 & 21.31 & 20.21 \\
\hline 156 & 33.57 & 35.67 & 32.43 & 33.89 & 18.61 & 17.74 & 19.71 & 18.69 \\
\hline
\end{tabular}


Table 6 Determination of the amounts of proteins produced by Pseudomonas taetrolens using the Bradford method

\begin{tabular}{ll}
\hline Sample & Amount of proteins $[\mu \mathrm{g} / \mathrm{ml}]$ \\
\hline after I centrifuge & 6,533 \\
$0.8 \mathrm{M}\left(\mathrm{NH}_{4}\right)_{2} \mathrm{SO}_{4}$ after II centrifuge & 34.5 \\
$1.2 \mathrm{M}\left(\mathrm{NH}_{4}\right)_{2} \mathrm{SO}_{4}$ after III centrifuge & 42 \\
$1.6 \mathrm{M}\left(\mathrm{NH}_{4}\right)_{2} \mathrm{SO}_{4}$ after IV centrifuge & 54.5 \\
$2.0 \mathrm{M}\left(\mathrm{NH}_{4}\right)_{2} \mathrm{SO}_{4}$ after V centrifuge & 58.6 \\
\hline
\end{tabular}

\section{Discussion}

Ahmad at al. 2004 have reported the toxicological investigations undertaken to evaluate the safety of a liquid enzyme concentrate, lactose oxidase, of this novel fungal oxidoreductase from $M$. nivale. The enzyme is expressed by a strain of $F$. venenatum and is produced by a submerged fermentation process and recovered by purification/concentration of the fermented culture broth. This introduction of the lactose oxidase gene into the recipient strain resulted in a $F$. venenatum production strain with significantly improved enzyme yields compared to what is obtainable by fermentation of the donor strain.

The enzyme is expressed by a strain of Escherichia coli and is produced by a submerged fermentation process and recovered by purification/concentration of the fermented culture broth. In our study, introduction of the glucose-fructose oxidareductase gene into the recipient strain resulted in an E. coli production strain with significantly improved enzyme yields compared to what is obtainable by fermentation of the donor strain.

Cheese whey was employed as a raw material for the production of lactobionic acid by $P$. taetrolens using a two-stage $\mathrm{pH}$-shifted bioconversion strategy, and lactobionic acid production of $42.4 \mathrm{~g} / \mathrm{L}$ with a $30 \%$ volume seed culture inoculum was obtained after $32 \mathrm{~h}$. Whey offers an alternative means to costly synthetic media with nutrient-mineral supplementation for lactobionic acid production. Further improvements concerning the influence of physical culture parameters on microbial behaviour as well as downstream processing are required for implementation of the process on an industrial level. [7]

The present study by Alonso et al. 2013 has demonstrated the feasibility of whey as an inexpensive source for lactobionic acid bio-production by $P$. taetrolens at an industrially relevant titer. A high-level titer of $180 \mathrm{~g} / \mathrm{L}$ was obtained with a yield of $90 \%$ via fed-batch cultivation carried out under co-feeding conditions. Moreover, the physiological responses of $P$. taetrolens cells were monitored through flow cytometry in order to assess the impact of different feeding strategies on bioprocess efficiency. High-yield bio-production of lactobionic acid was directly linked to the fully functional status of $P$. taetrolens, thus providing relevant information for successful industrial implementation.

Table 7 Changes of Pseudomonas taetrolens counts during the process of lactose oxidation to lactobionic acid

\begin{tabular}{ll}
\hline & $\begin{array}{l}\text { Colony forming units } \\
{[\mathrm{CFU} / \mathrm{ml}]}\end{array}$ \\
\hline Inoculum after 24 $\mathrm{h}$ & $2.8 \times 10^{9}$ \\
Bioreactor stationary method after 24 h & $3.3 \times 10^{8}$ \\
Bioreactor continuous culture after 24 h & $7.0 \times 10^{9}$ \\
\hline
\end{tabular}




\section{Conclusions}

Lactobionic acid was produced as a result of enzymatic oxidation of lactose. Environmental factors affecting the yield of lactobionic acid were analysed, i.e. temperature and culture time. Optimal conditions for the production of this acid were found to be 48 -h oxidation of lactose at $30^{\circ} \mathrm{C}$.

Certain irregularities were observed in the presented results, since in certain variants, the content of lactose increased. The content of oxidized sugar during culture should decrease due to the fact that lactose is transformed by exocrine enzymes in the first stage to lactobionic- $\delta$ lactone, and subsequently to the molecule of lactobionic acid.

Conducted experiments confirmed that both the time and temperature influenced the production of lactobionic acid during bioconversion of lactose using the P. taetrolens bacteria.

The study also investigated the effect of inoculum concentration on the production of lactobionic acid as a result of oxidation of whey-derived lactose. The highest concentration of lactobionic acid during oxidation of whey-derived lactose at a temperature of $30{ }^{\circ} \mathrm{C}$ by microorganism $P$. taetrolens was obtained during 50-h oxidation of the medium, which contained $25 \%$ addition of the inoculum, in which the count of live cells was $2.85 \times$ $10^{9} \mathrm{CFU} / \mathrm{ml}$.

Results of electrophoresis run by SDS-PAGE confirm in proteins salted out of the culture the presence of exocrine enzymes secreted by microorganisms $P$. taetrolens-i.e., lactonase with molecular weight of $28 \mathrm{kDa}$ and lactose oxidase with molecular weight of $55 \mathrm{kDa}$.

Both the quantitative determination of proteins by Bradford's method and electrophoretic determinations confirm the presence of enzymes produced by microorganisms $P$. taetrolens.

Acknowledgments The authors thank the Polish Ministry of Science and Higher Education for the financial support (grant no. N N 312 441737) of this research project.

Open Access This article is distributed under the terms of the Creative Commons Attribution License which permits any use, distribution, and reproduction in any medium, provided the original author(s) and the source are credited.

\section{References}

1. Gutierrez, L. F., Hamoudi, S., \& Belkacemi, K. (2012). International Dairy Journal, 26, 103-111.

2. Douka, E., Koukkou, A. I., Vartholomatos, G., Frillingos, S., Papamichael, E. M., \& Drainas, C. (1999). Journal of Bacteriology, 181, 4598-4604.

3. Druliolle, H., Kokoh, K. B., Hahn, F., Lamy, C., \& Beden, B. (1997). Journal of Electroanalytical Chemistry, 426, 103-115.

4. Gutierrez, L. F., Hamoudi, S., \& Belkacemi, K. (2011). Applied Catalysis A: General, 402, 94-103.

5. Gänzle, M. G., Haase, G., \& Jelen, P. (2008). International Dairy Journal, 18(7), 685-694.

6. Ahmad, S. K., Brinch, D. S., Friis, E. P., \& Pedersen, P. B. (2004). Regulatory Toxicology and Pharmacology, 39, 256-270.

7. Alonso, S., Rendueles, M., \& Díaz, M. (2011). Bioresource Technology., 102, 9730-9736.

8. Bradford, M. M. (1976). Analytical Biochemistry, 72, 248-254.

9. Trojanowska, K., Giebel, H., \& Gołębiewska, B. (2004). Food Microbiology (pp. 113-115). Poznań, Poland: Poznan University of Life Sciences.

10. Wang, L., Weng, L., Dong, Y., \& Zhang, L. (2004). Journal of Biological Chemistry, 279, 13645-13651. 